\section{To: (Receiving Organization) \\ Distribution}

\section{Proj./Prog./Dept./Div.: $101-S Y / H M$}

8. Originator Remarks:

For approval and release.
3. From: (Originating Organization)

Packaging Programs and

Transportation (84400)

6. Cog. Engr.:

S. H. Shaw
4. Related EDT Ho.:

NA

7. Purchase Order No.:

NA

9. Equip./Component No.:

NA

10. System/Bldg./Facility: 101-SY

\section{Receiver Remarks:}

12. Major Assm. Dwg. No.:
13. Permit/Permit Application No.:

14. Required Response Date:

February 3, 1995

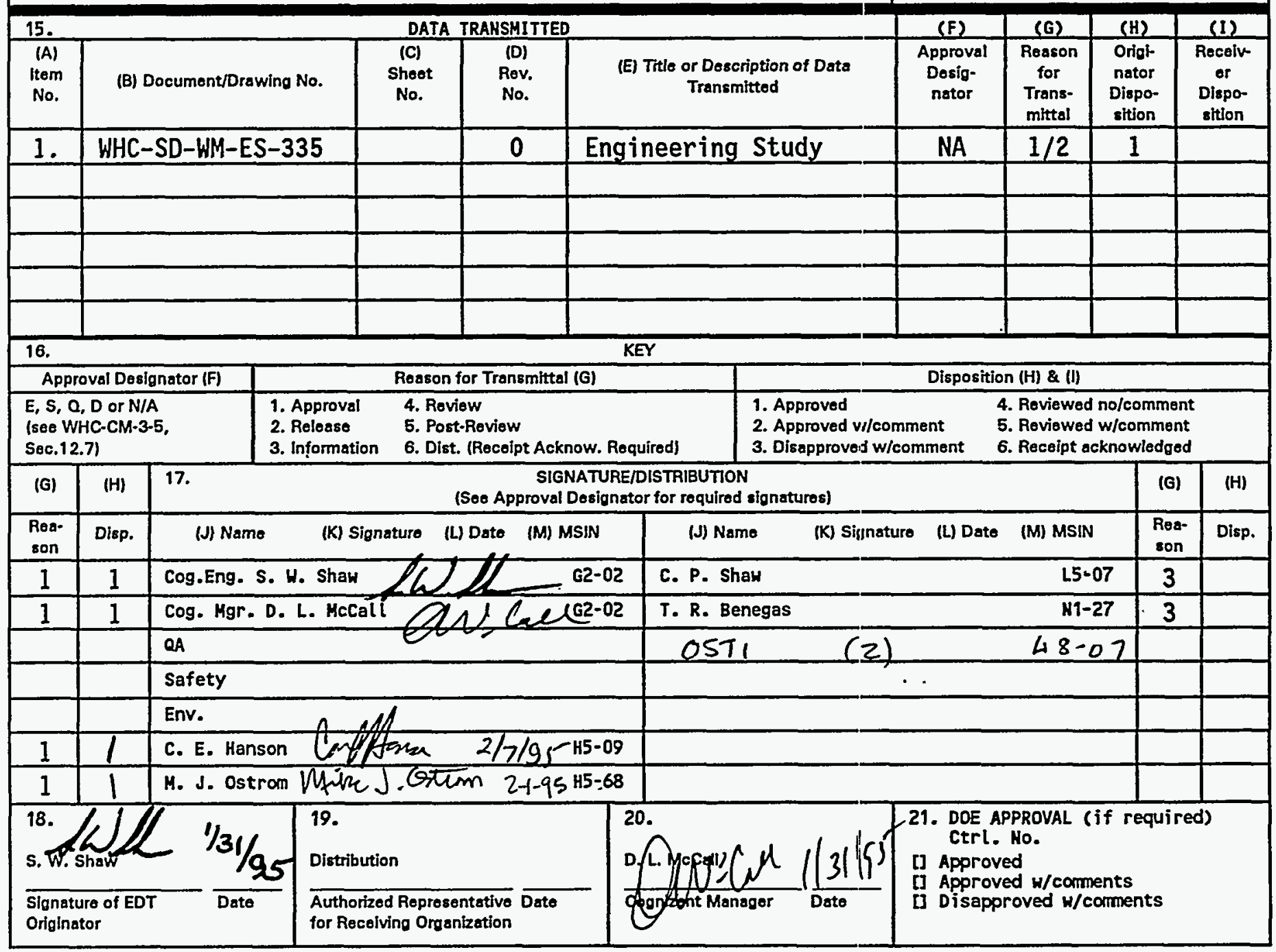




\section{DISCLAIMER}

Portions of this document may be illegible in electronic image products. Images are produced from the best available original document. 


\section{RELEASE AUTHORIZATION}

Document Number: WHC-SD-WM-ES-335, Rev. 0

$\begin{array}{ll}\text { Document Title: } & \text { 101-SY Dome Pressure Issues Surrounding Mitigation } \\ \text { Pump Decontamination During Removal }\end{array}$

Release Date: $\quad 2 / 17 / 95$

\section{This document was reviewed follovving the procedures described in WHC-CM-3-4 and is:}

\section{APPROVED FOR PUBLIC RELEASE}

WHC Information Release Administration Specialist:
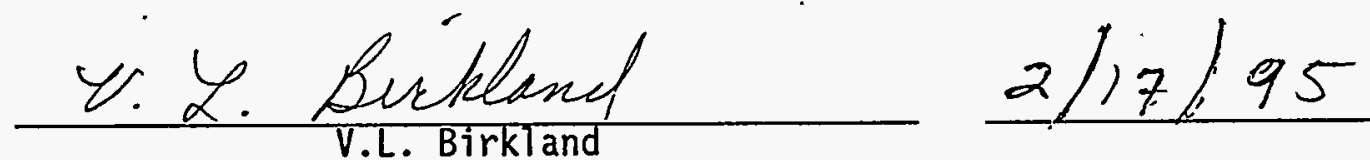

V.L. Birkland

TRADEMARK DISCLAIMER. Reference herein to any specific comercial product, process, or service by trade name, trademark, manufacturer, or otherwise, does not necessarily constitute or imply its endorsement, recommendation, or favoring by the United States Government or any agency thereof or its contractors or subcontractors.

This report has been reproduced from the best available copy. Available in paper copy and microfiche. Printed in the United States of America. Available to the U.S. Departmerit of Energy and its contractors from:

U.S. Department of Energy

office of Scientific and. Technical Information (OSTI)

P.0. Box 62

Oak Ridge, TN 37831

Telephone: (615) 576-8401

Available to the public from:

U.S. Department of Commerce

Hational Technical Information Service (NTIS)

5285 Port Royal Road

Springfield, VA 22161

Telephone: (703) 487-4650 


\begin{tabular}{|l|l|c|}
\hline $\begin{array}{l}\text { 2. Title } \\
\text { 101-SY DOME PRESSURE ISSUES SURROUNDING MITIGATION } \\
\text { PUMP DECONTAMINATION DURING REMOVAL }\end{array}$ & $\begin{array}{c}\text { 3. Humber } \\
\text { WHC-SD-WM-ES-335 }\end{array}$ & 0 \\
\hline $\begin{array}{l}\text { 5. Key Hords } \\
\text { 101-SY, DOME PRESSURE, DECONTAMINATION, MITIGATION } \\
\text { PUMP, SPRAYWANDS }\end{array}$ & $\begin{array}{l}\text { 6. Author } \\
\text { Same: }\end{array}$ & Signatire W. Shaw \\
\hline
\end{tabular}

\section{Abstract}

This document addresses issues related to use of the spraywands and ring used to decontaminate the mitigation pump installed in 101-SY. It has been determined that use of the wands will influence tank dome pressures as a function of ventilation system configuration, spray drop size, rinse water temperature, and rate at which spraywand flows are established.

8. RELEASE STAMP

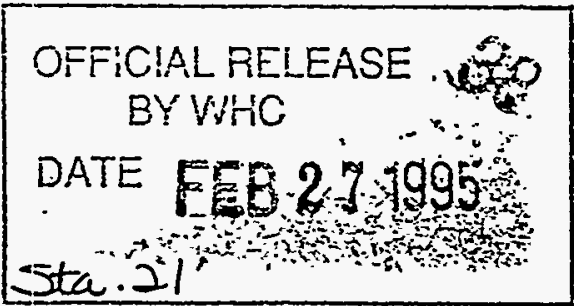




\title{
101-SY DOME PRESSURE ISSUES SURROUNDING MITIGATION PUMP DECONTAMINATION DURING REMOVAL.
}

\author{
WHC-SD-WH-ES-335 \\ REV 0 \\ January 31, 1995 \\ by \\ S. W. Shaw \\ Packaging Programs and Testing
}

\section{DISCLAIMER}

This report was prepared as an account of work sponsored by an agency of the United States Government. Neither the United States Government nor any agency thereof, nor any of their employees, makes any warranty, express or implied, or assumes any legal liability or responsibility for the accuracy, completeness, or usefulness of any information, apparatus, product, or process disclosed, or represents that its use would not infringe privately owned rights. Reference herein to any specific commercial product, process, or service by trade name, trademark, manufacturer, or otherwise does not necessarily constitute or imply its endorsement, recommendation, or favoring by the United States Government or any agency thereof. The views and opinions of authors expressed herein do not necessarily state or reflect those of the United States Government or any agency thereof.

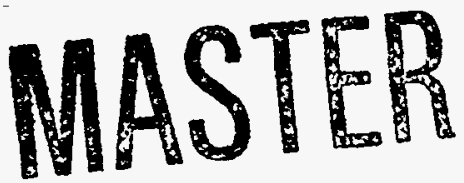


WHC-SD-WM-ES-335

Rev. 0

TABLE OF CONTENTS

1.0 INTRODUCTION . . . . . . . . . . . . . . . . 1

1.1 SY EXHAUST SYSTEM CONFIGURATION . . . . . ....... 1

1.2 INITIAL RECOMMENDATION ................. I

2.0 ANALYSIS PERFORMED ................. 2

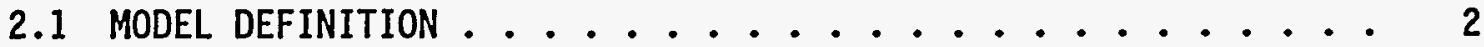

2.1 .1 Drop Size Issues ............... 2

2.2 CASES OF INTEREST $\ldots \ldots 3$

2.3 COMPARISON OF GOTHIC PREDICTED RESULTS TO HISTORICAL DATA

FROM WATER LANCING ................ 9

3.0 PRESENT CONTROLS FOR WATER WAND OPERATION $\ldots \ldots . \ldots$

4.0 PROPOSED CONTROLS FOR HATER WAND OPERATION .......... 11

4.1 ISSUES SURROUNDING PRESSURE/FLOW CALCULATIONS ....... 11

4.2 PRESSURE MEASUREMENT RELATED ISSUES .......... 12

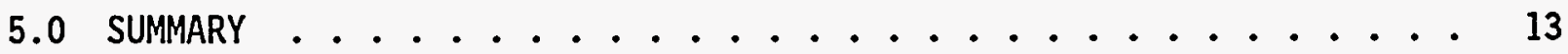

6.0 CONCLUSIONS AND RECOMMENDATIONS .............. 13

\section{LIST OF FIGURES}

Figure 1. Flow Rate vs Time for Spraywands.................... 4

Figure 2. - Flow Rate vs Time for Spray Ring-Instant On.............4

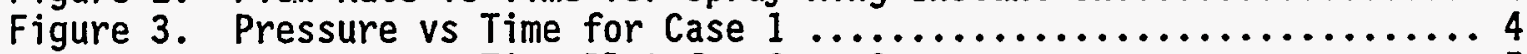

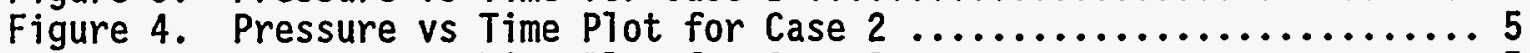

Figure 5. Pressure vs Time Plot for Case $3 \ldots \ldots \ldots \ldots \ldots \ldots \ldots \ldots \ldots, 5$

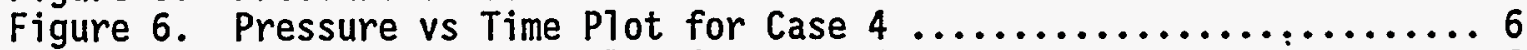

Figure 7. Pressure vs Time Plot for Case $5 \ldots \ldots \ldots \ldots \ldots \ldots \ldots \ldots \ldots 6$

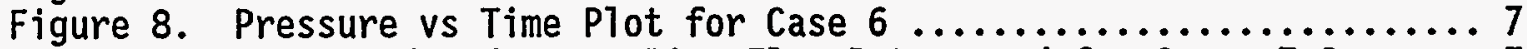

Figure 9. Spraywand and Spray Ring Flow Rates used for Cases 7-9 $\ldots . .77$

Figure 10. Pressure vs Time Plot for Case $7 \ldots \ldots \ldots \ldots \ldots \ldots \ldots \ldots, \ldots$

Figure 11. Pressure vs Time Plot for Case $8 \ldots \ldots \ldots \ldots \ldots \ldots \ldots \ldots \ldots, 8$

Figure 12. Pressure vs Time PTot for Case $9 \ldots \ldots \ldots \ldots \ldots \ldots \ldots \ldots \ldots$

Figure 13. GOTHIC Predicted Pressure vs Time Plot for Water Lancing ... 10

Figure 14. Pressure vs Time PTot Data from DACs for Water Lancing ..... 10

\section{LIST OF TABLES}

TABLE 1 Analysis Case Summary $\ldots \ldots \ldots \ldots \ldots \ldots \ldots \ldots \ldots \ldots \ldots \ldots \ldots, \ldots \ldots$ 
HHC-SD-WM-ES-335

Rev. 0

\section{ABBREVIATIONS AND ACRONYMS}

$\begin{array}{ll}\text { CFM } & \text { Cubic Feet per Minute } \\ \text { DAC } & \text { Data Acquisition and Control } \\ \text { DP } & \text { Difference in Pressure } \\ \text { GPM } & \text { Gallons per Minute } \\ \text { HEPA } & \text { High Efficiency Particulate Air } \\ \text { L } & \text { Liter } \\ \text { SSSF } & \text { Steady State Steady Flow } \\ \text { atm } & \text { atmosphere } \\ \text { Cm } & \text { centimeter } \\ \text { in wg } & \text { inches water gauge } \\ \text { min } & \text { minute } \\ \text { psi } & \text { pounds per square inch }\end{array}$


WHC-SD-INM-ES-335

Rev. 0

Page 1 of 13

\section{1-SY DOME PRESSURE ISSUES SURROUNDING MITIIIATION PUMP DECONTAMINATION DURING REMOVAL}

\subsection{INTRODUCTION}

During the July, 1993 water lancing in 101-SY, moisture entrained in the exhaust air stream plugged the High Efficiency Particulate Air (HEPA) filters, and resulted in the unplanned shutdown of the K-1 exhaust system. In May of 1994, it was requested that a recommendation be made with respect to the configuration of the ventilation system during removal and decontamination of the SY mitigation pump.

At that time, decontamination of the pump was to be accomplished using a spray ring attached to the pump's load frame located in the pump pit, and two spraywands located in risers (13A and 23A) adjacent to the pump. Present planning calls for the installation of an additional spraywand in riser $3 A$, raising the total number of spraywands to three. The spraywands offer the benefit of removing a large portion of the waste from the pump prior to the final rinse in the pump pit.

However, use of the spraywands also incurs the 1 iability of increased moisture in the tank dome. This moisture would lead to plugging of the $\mathrm{K}-1$ system's HEPA filters, similar to the incident with the water lancing. Additionally, contamination in the form of aerosols would cause undesirable contamination of the exhaust header. Finally, rupture of the HEPA's resulting from a high differential pressure incurred as a result of their saturation with water was deemed a possibility.

\subsection{SY EXHAUST SYSTEM CONFIGURATION}

The exhaust system for the tanks maintains them at a pressure less than atmospheric, ensuring that air flows into the tank, providing a means of contamination control. Air enters the tank through a $310.48 \mathrm{~cm}$ (12") diameter HEPA filter inlet, and exits through a 30.48 (12") header, which handles the $28320 \mathrm{~L} / \mathrm{min}$ ( $1000 \mathrm{CFM}$ ) combined air flow of tanks 101,? and 3 SY. Dampers are provided at each tank outlet to throttle their individual flow rates through the system. The exhaust air passes through a moisture separator intended to remove entrained moisture. It then flows through a heater section, intended to lower the relative humidity of the exhaust air stream. Finally, it flows through a HEPA filter to remove any entrained radioactive contaminants, and exhausted to atmosphere.

Historically, the moisture handling capabilities of the system have been found wanting. High differential pressures, the result of moisture loading of the HEPA filters, are observed during periods of inclement weather (ie. when it rains).

\subsection{INITIAL RECOHMENDATION}

Based on the systems lack of capacity with respect to moisture in the exhaust air stream, the potential for contamination of the exhaust header, the remote yet possible rupture of the exhaust HEPA filter, and the high humidity/aerosol content expected for the tank dome during mitigation pump decon, it was recommended that the ventilation system be shut down for the 
WHC-SD-WM-ES-335

Rev. 0

Page 2 of 13

approximately 45 minutes that it would take to remove the pump mitigation pump from 101-SY.

\subsection{ANALYSIS PERFORMED}

To determine the possible consequences of shutting down the exhaust system, the 101-SY dome space, and ventilation system were modeled using the GOTHIC computer code to determine changes in tank dome pressure and temperature during operation of the sprays.

\subsection{MODEL DEFINITION}

For a 71 cases, the initial tank gas space temperature was $32.2{ }^{\circ} \mathrm{C}$ $\left(90^{\circ} \mathrm{F}\right)$, and the relative humidity was $20 \%$. Atmospheric temperature was $25{ }^{\circ} \mathrm{C}$ $\left(77^{\circ} \mathrm{F}\right)$, and the relative humidity was $33 \%$. For the cases in which the 101-SY ventilation flow was $11,320 \mathrm{~L} /$ min $(400 \mathrm{CFM}$ ), the initial tank pressure was $-498.2 \mathrm{~Pa}\left(-2^{\prime \prime} \mathrm{wg}\right)$. For the cases with zero ventilation system flow, the initial tank pressure was atmospheric.

Water addition to the tank dome space were modeled as wand sprays, which are located within the gas space, and operate at $227.5 \mathrm{~L} / \mathrm{min}(60 \mathrm{gpm})$, and the spray ring, located in the pump pit, which operates at $454.2 \mathrm{~L} / \mathrm{min}$ (120 gpm). Flow from the ring sprays was assumed to leak into the gas space as a solid stream of water at the same rate as it was produced. Flow from the wand sprays was assumed to enter the gas space as droplets. The size of the droplets were calculated from a drop size distribution used by Steve Roblyer in previous 101-SY spray calculations. The value used in the analysis was the mean drop diameter, which was determined to be about 6 inicrons.

\subsubsection{Drop Size Issues}

The smaller the drop size, the greater the surface area of the injected water, and resulting heat/mass transfer. The nozzles used in the spraywands produce a steady stream of water. What is needed to make the GOTHIC model more closely reflect actual conditions in the tank during mitigation pump decon is a "rebound mean drop diameter," the mean drop size after the solid spray streams have impacted on the pump. The nozzle vendor was contacted in an effort to obtain more accurate data. Not surprisingly, the vendor was unable to supply any meaningful rebound drop size inforination for sprays impacting a variety of waste coated curved surfaces at an angle. Intuitively, drops on the order of 1500 microns (1/16") were expected however.

A significant amount of energy has been expended in trying to develop a more reasonable approximation of the mean drop diameter. Analysis performed shows that one of the most significant factors effecting the predicted pressure changes in the tank dome is the value used for the drop size. A comparison of Figures 6 (6 mircron drop) and 7 (1500 micron drop) demonstrates the significance of drop size on analytical results.

Unable to determine a more realistic value for mean drop diameter, Roblyer's values were used, with the knowledge that this would result in a conservative result. 
WHC-SD-HM-ES-335

Rev. 0

Page 3 of 13

\subsection{CASES OF INTEREST}

A number of model cases were run to determine the sensitivity of the tank dome pressure to changes in ventilation flow rates, decon water temperatures, inlet/exhaust riser configuration, the raties at which spraywand flows were increased, and just as a point of interest, one case with the mean drop diameter at 1500 microns (1/16"), as opposed to the 6 microns used in a11 other cases.

The nine cases summarized in the table below can used to demonstrate the effects mentioned above. Figures 1 and 2 show the flow rates (instant on) for the spraywands and ring in cases $1-6$. Figure 9 shows the spraywand flow rates with respect to time for cases $7-9$, where the wand flow rate was incrementally stepped up to their fu17 $227.5 \mathrm{~L} / \mathrm{min}(60 \mathrm{gpm})$ flow.

TABLE 1

ANALYSIS CASE SUMMARY

\begin{tabular}{|c|c|c|c|c|c|}
\hline $\begin{array}{l}\text { Case } \\
\text { number }\end{array}$ & $\begin{array}{c}\text { Vent } \\
\text { Flow } \\
\text { L/min(CFY) }\end{array}$ & $\begin{array}{l}\text { Wand } \\
\text { spray frow } \\
\text { gfint(gpm) }\end{array}$ & 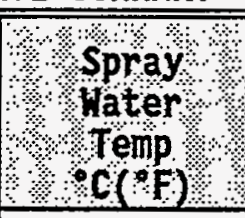 & $\begin{array}{l}\text { Exhaust } \\
\text { Damper } \\
\text { Setting }\end{array}$ & $\begin{array}{c}\text { Reference } \\
\text { Figure } \\
\text { ? }\end{array}$ \\
\hline 1 & $11327(400)$ & $227(60)$ & $21(70)$ & Open & 3 \\
\hline 2 & $11327(400)$ & $227(60)$ & $32(90)$ & Open & 4 \\
\hline 3 & $11327(400)$ & $227(60)$ & $43(110)$ & Open & 5 \\
\hline 4 & 0 & $227(60)$ & $32(90)$ & Closed & 6 \\
\hline $5^{*}$ & 0 & $227(60)$ & $32(90)$ & Closed & 7 \\
\hline 6 & 0 & $227(60)$ & $32(90)$ & Open & 8 \\
\hline 7 & 0 & $227(60)$ & $21(70)$ & Open & 10 \\
\hline 8 & 0 & $227(60)$ & $32(90)$ & Open & 11 \\
\hline 9 & 0 & $227(60)$ & $43(110)$ & Open & 12 \\
\hline
\end{tabular}

* 1500 microns (1/16") Used as mean drop diameter.

A comparison of cases 1,2 and 3 demonstrates the effect of decon water temperature on the dome pressure. Cases 2 and 4 can be compared to determine the impact of turning the ventilation system off, and closing the exhaust damper. Cases 2 and 6 can be compared to see the effect of turning the ventilation system off, with the exhaust damper open. A comparison between cases 4 and 6 demonstrate the effects of opening the exhaust damper, with the ventilation system off. A comparison of cases 4 and 5 demonstrate the sensitivity of the analysis to mean drop diameter. Comparing cases 6 to 8 shows the effect of stepping up the spraywand flow rates, as opposed to the instant on version. And finally, a comparison of cases 7, 8, and 9 demonstrates the effects of water temperature when the spray wands are stepped up to full flow. 
WHC-SD-WM-ES-335

Rev. 0

Page 4 of 13
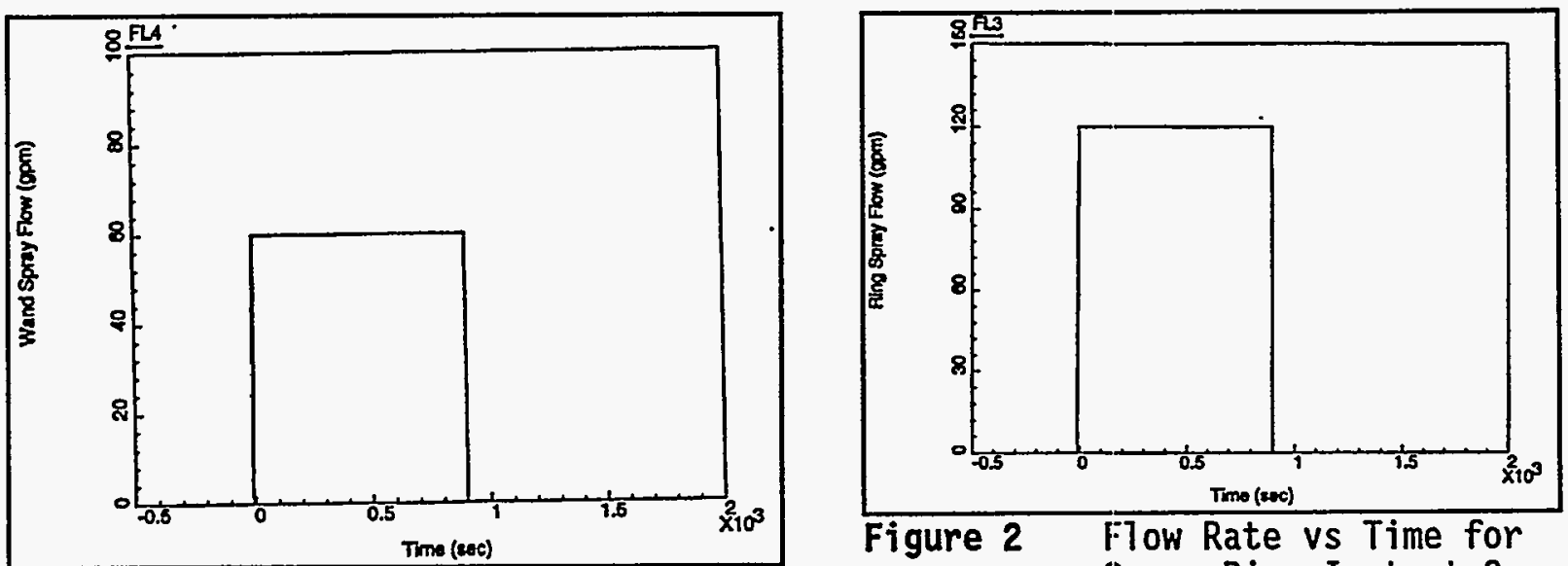

Figure 2 Fow Rate vs Time for Spray Ring-Instant on

Figure 1 Flow Rate vs Time for Spraywands

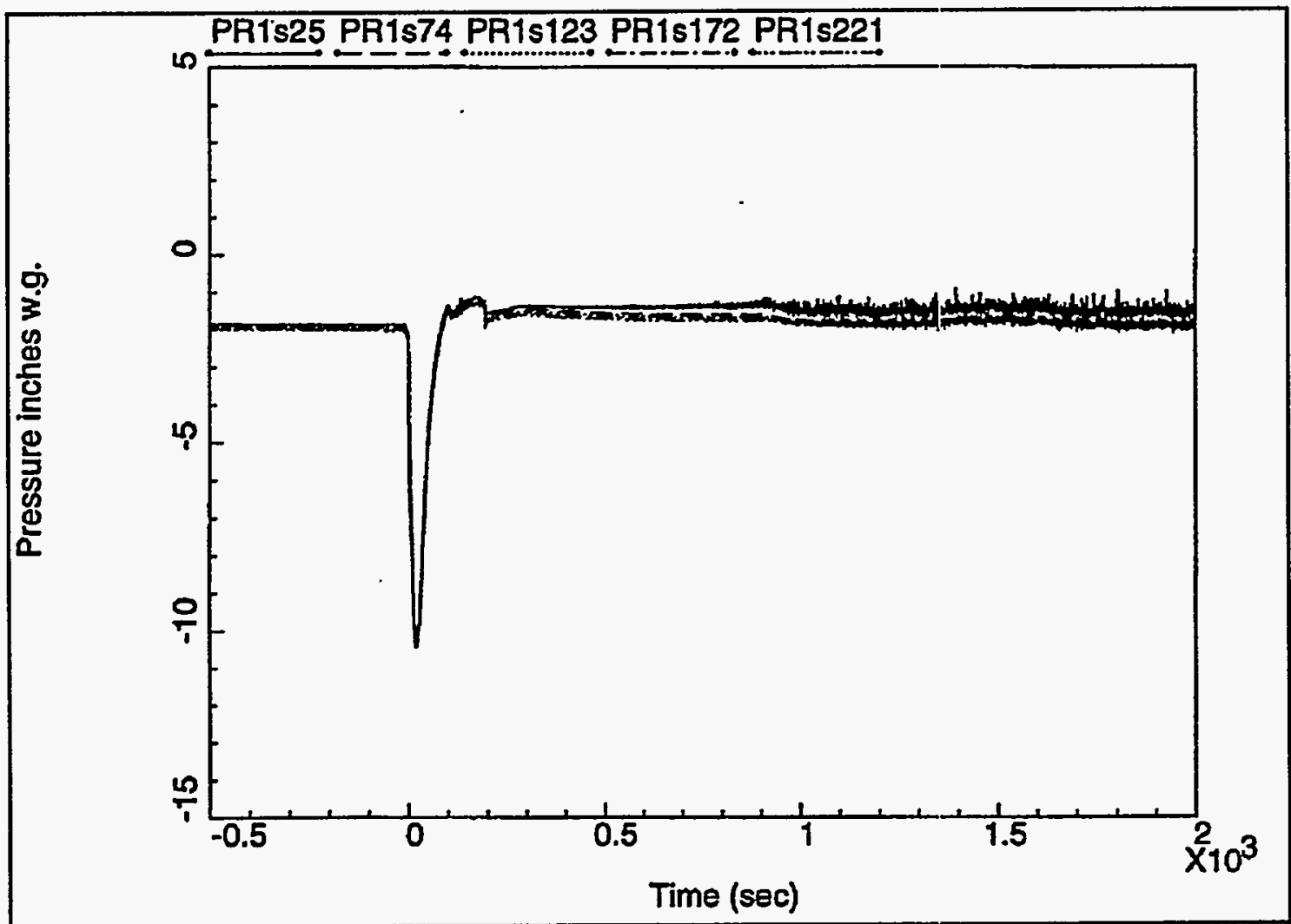

Figure 3 Pressure vs Time for Case 1 
WHC-SD-WMM-ES-335

Rev. 0

Page 5 of 13

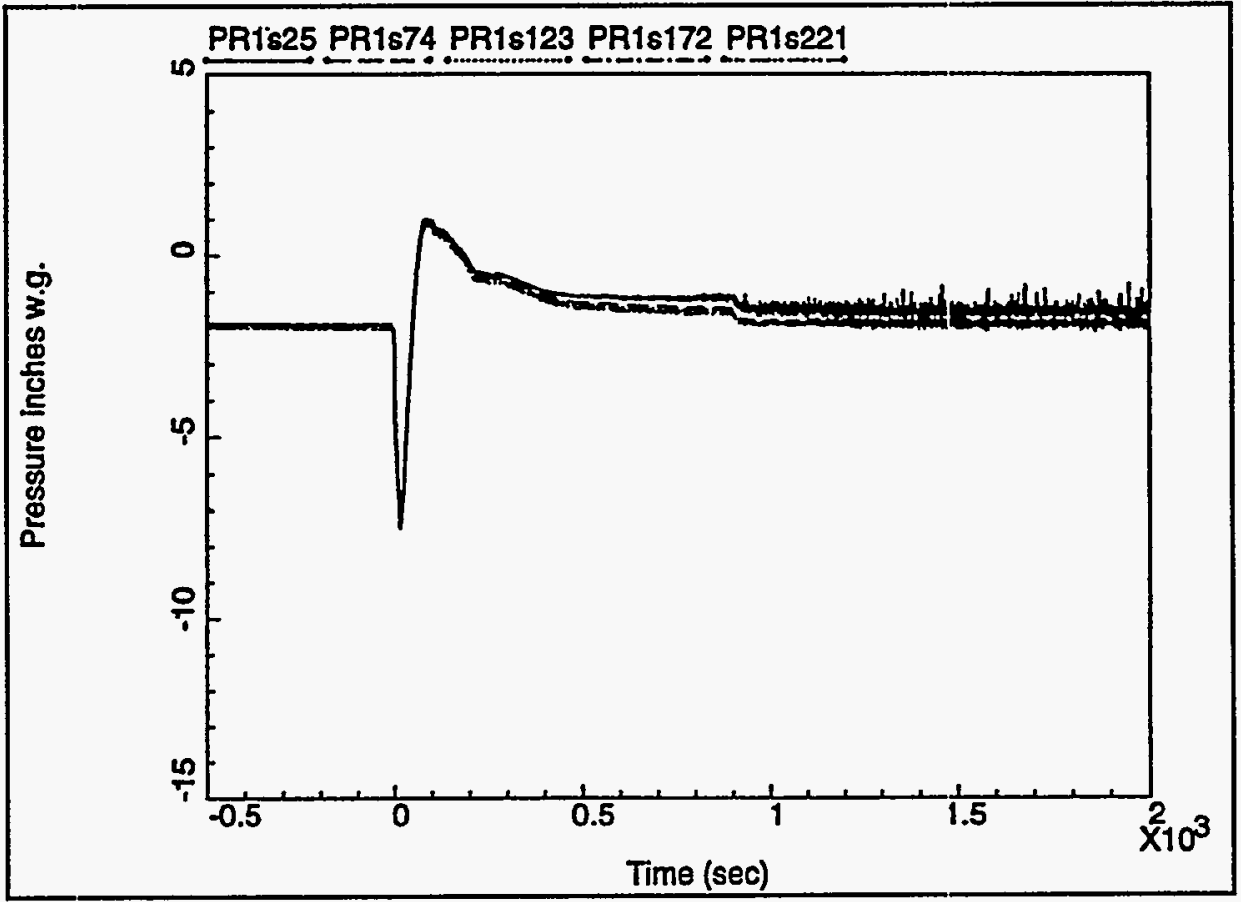

Figure 4 Pressure vs Time Plot for Case 2

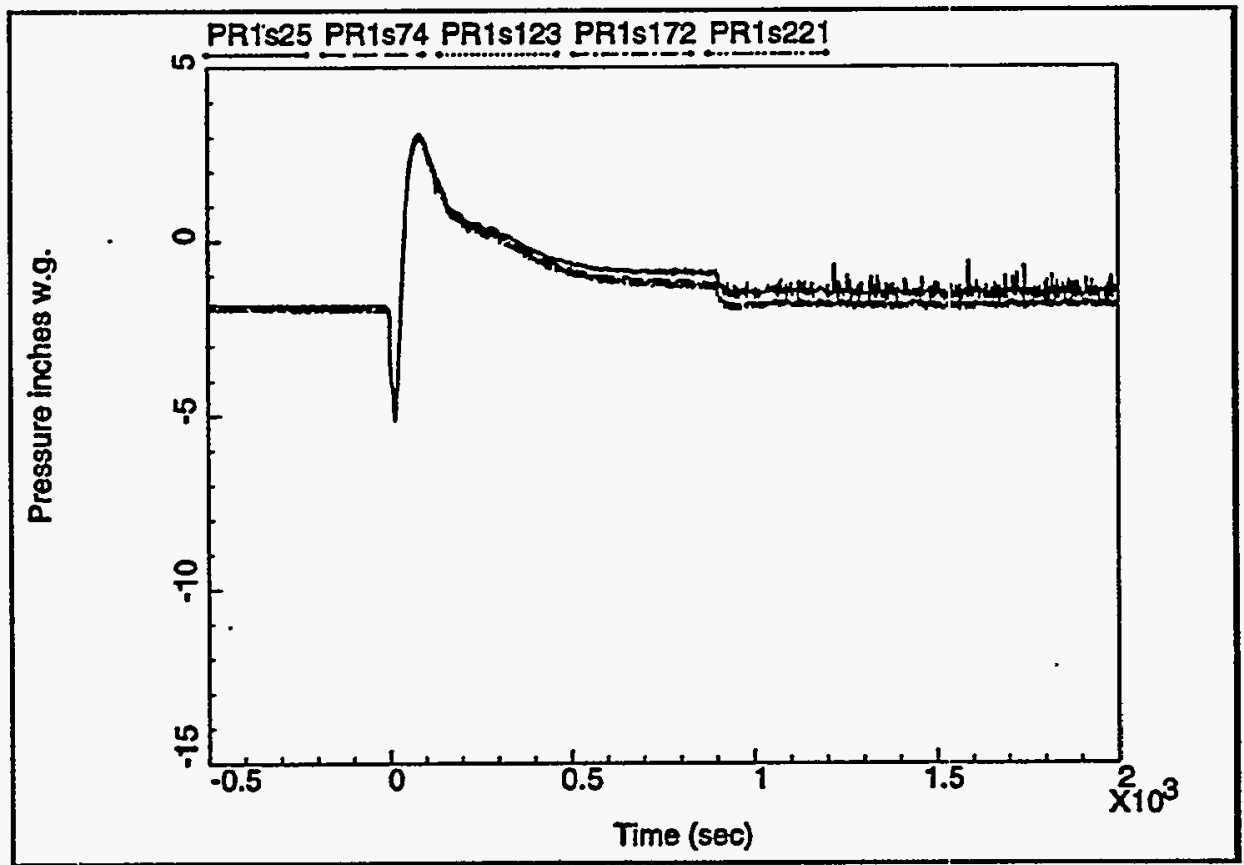

Figure 5 Pressure vs Time Plot for Case 3. 
HHC-SD-WM-ES-335

Rev. 0

Page 6 of 13

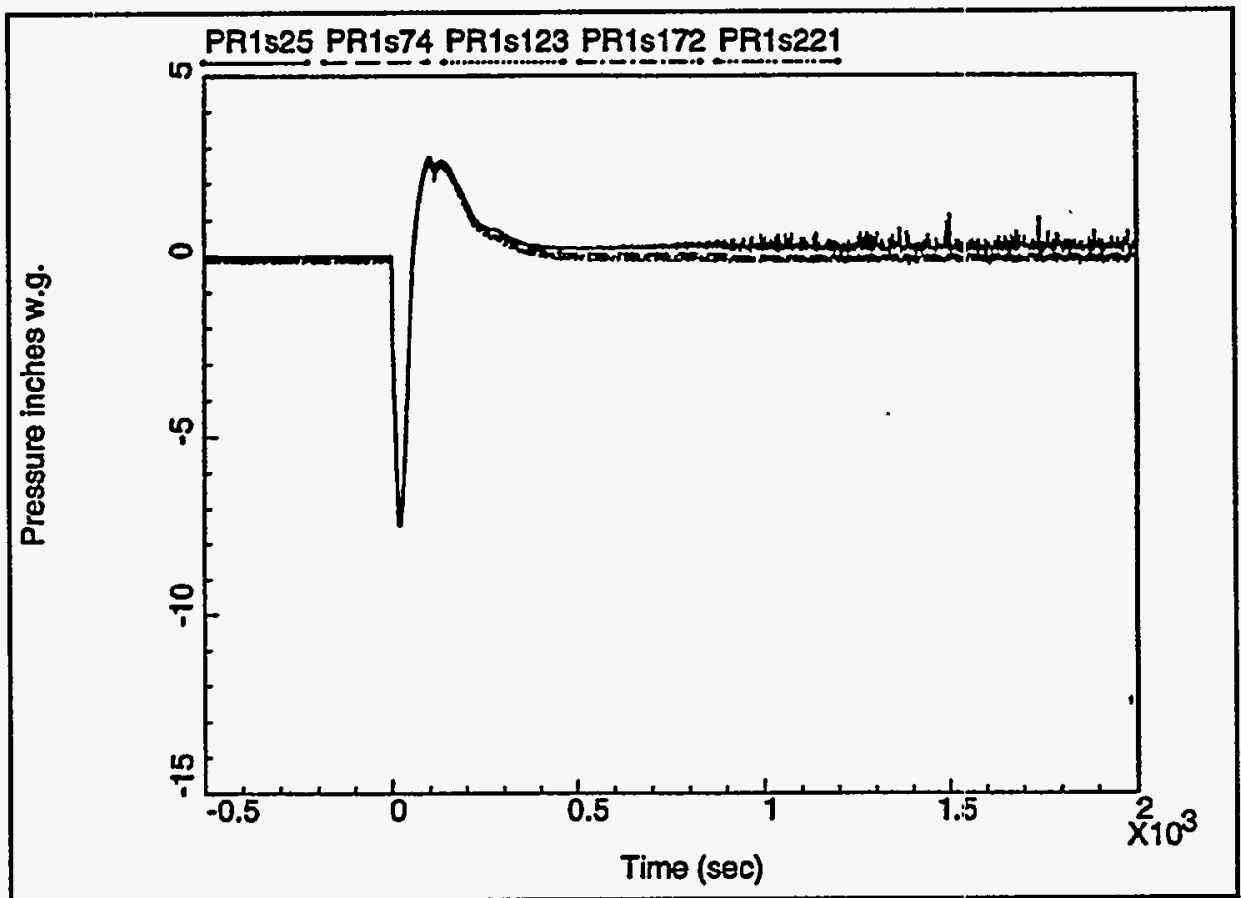

Figure 6 Pressure vs Time Plot for Case 4.

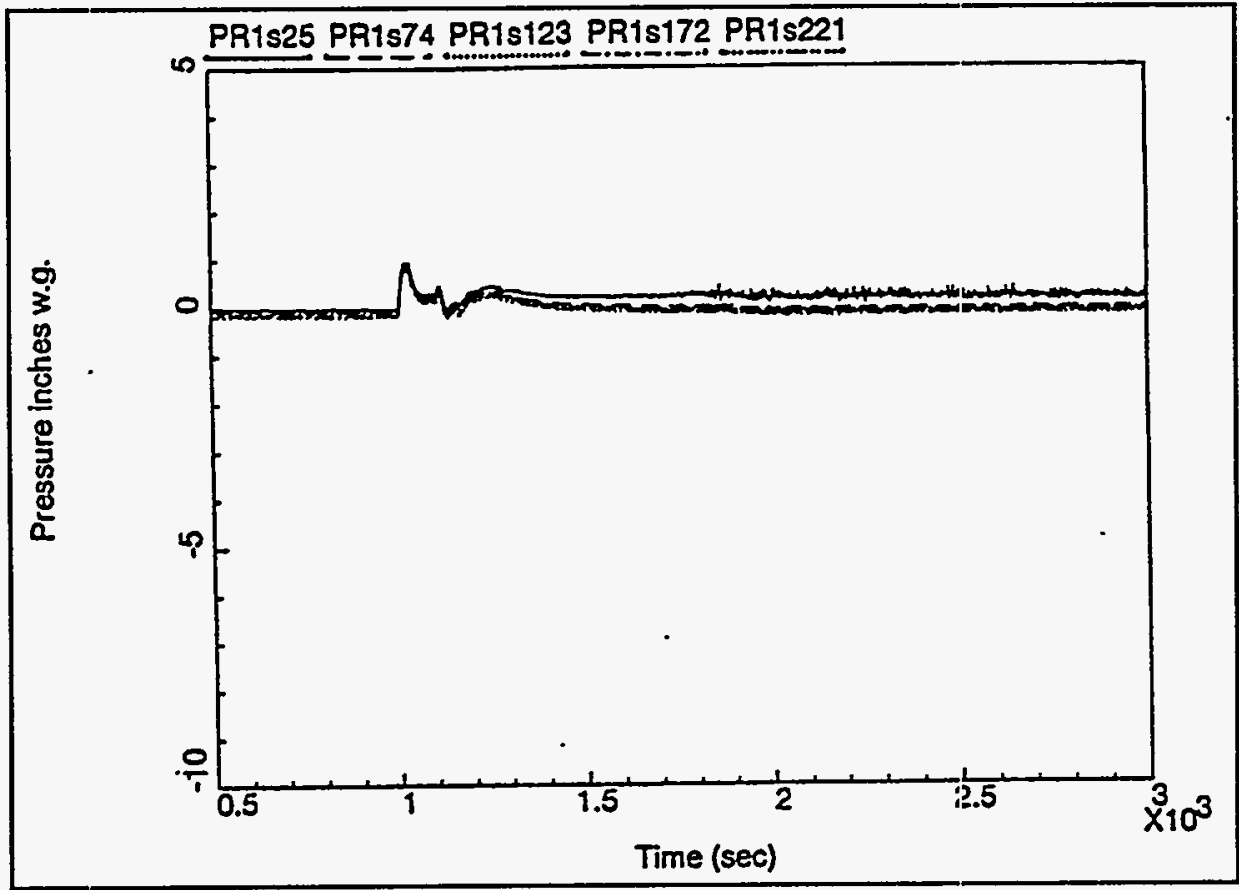

Figure 7 Pressure vs Time Plot for Case 5. 
WHC-SD-WM-ES-335

Rev. 0

Page 7 of 13

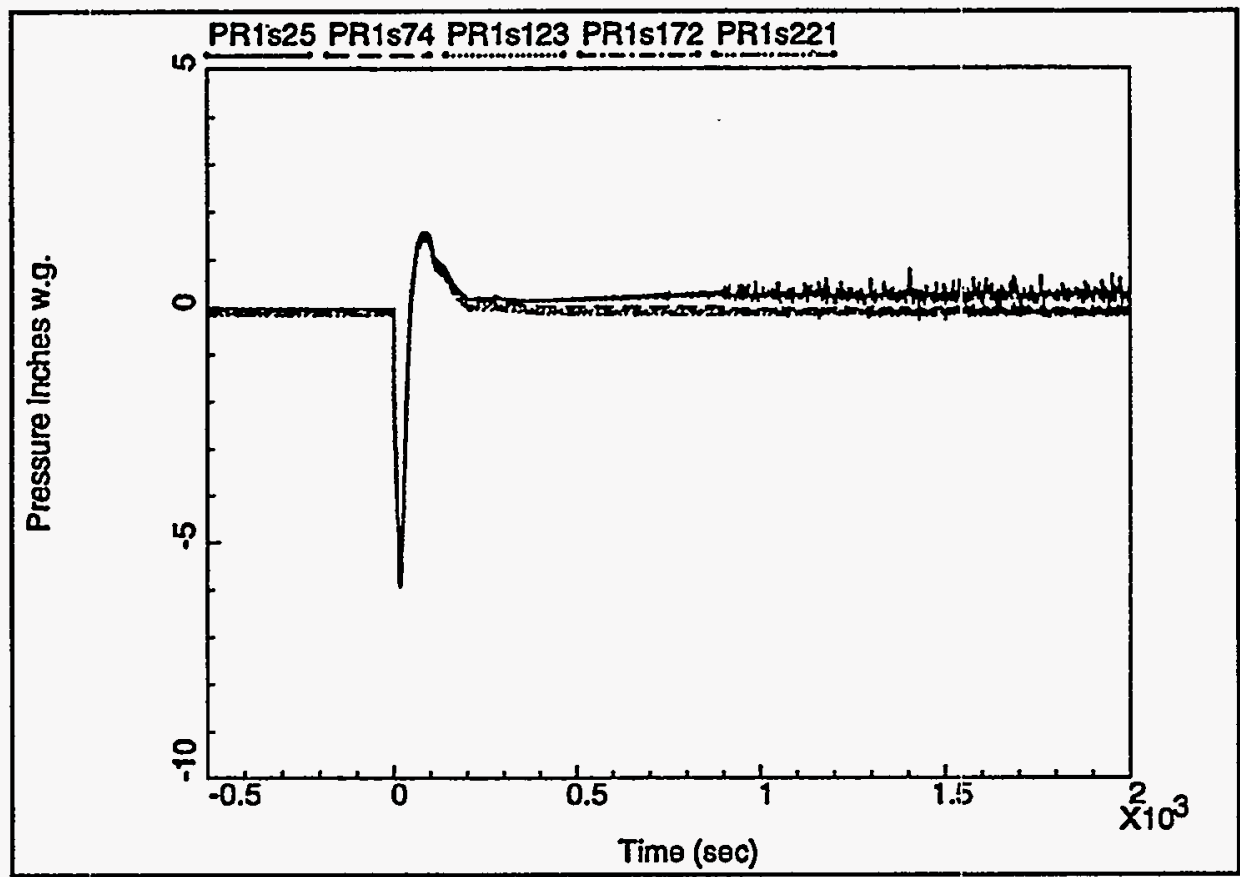

Figure 8 Pressure vs Time Plot for Case 6.

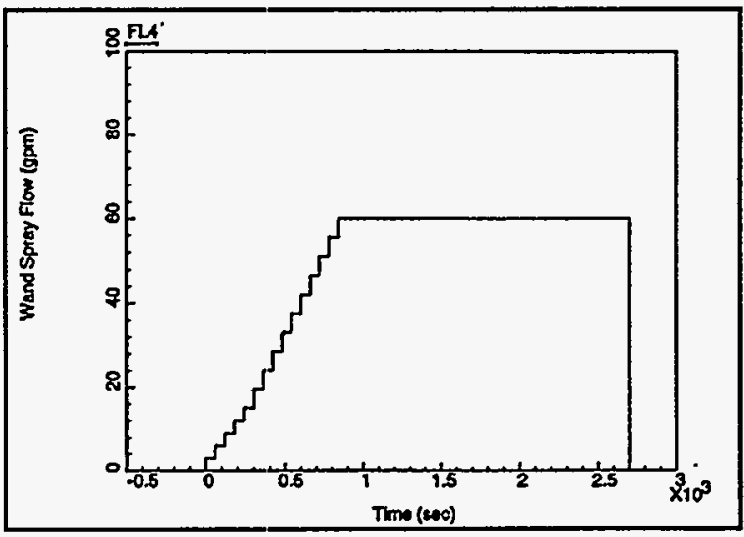

Hand Flow Rate vs Time

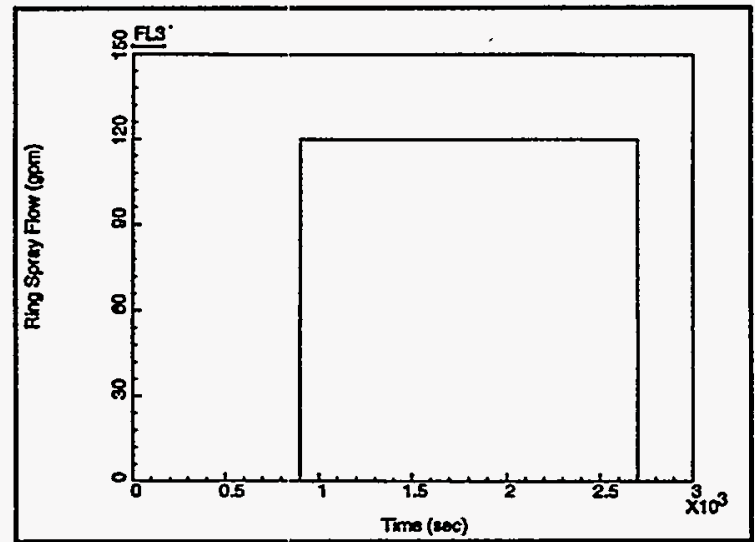

Spray Ring Flow Rate vs Time

Figure 9 Spraywand and Spray Ring Flow Rates used for Cases 7 - 9. 
Rev. 0

Page 8 of 13

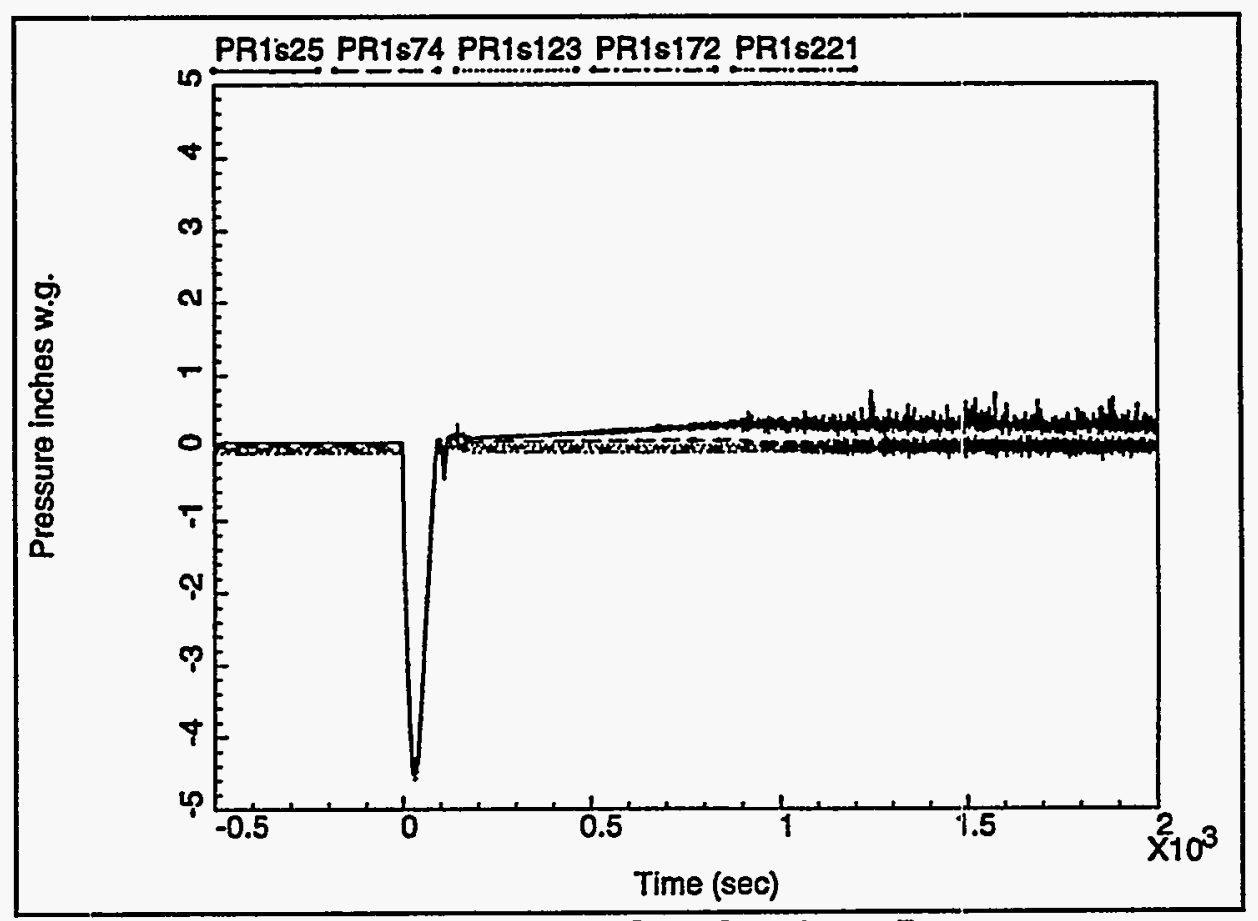

Figure 10 Pressure vs Time Plot for Case 7.

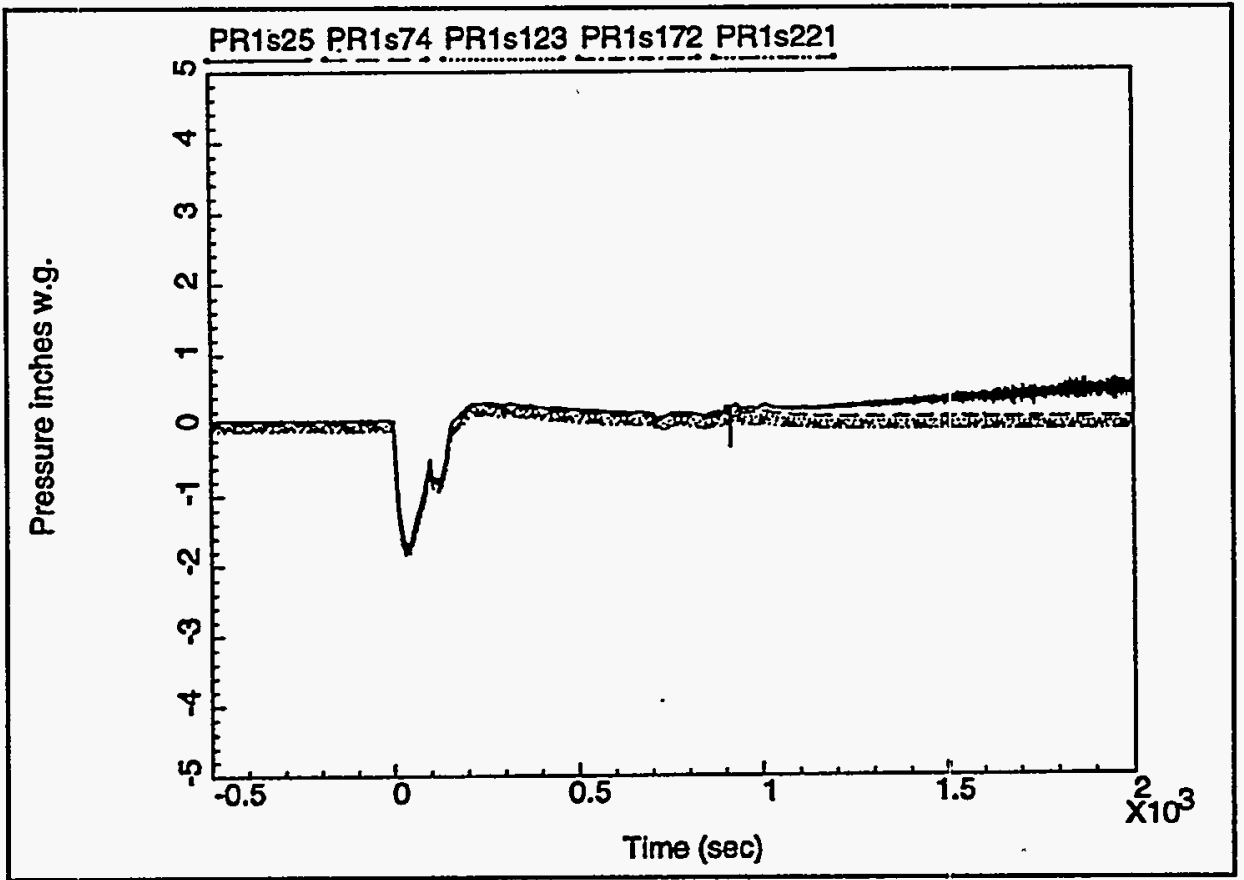

Figure 11 Pressure vs Time PTot for Case 8. 
Rev. 0

Page 9 of 13

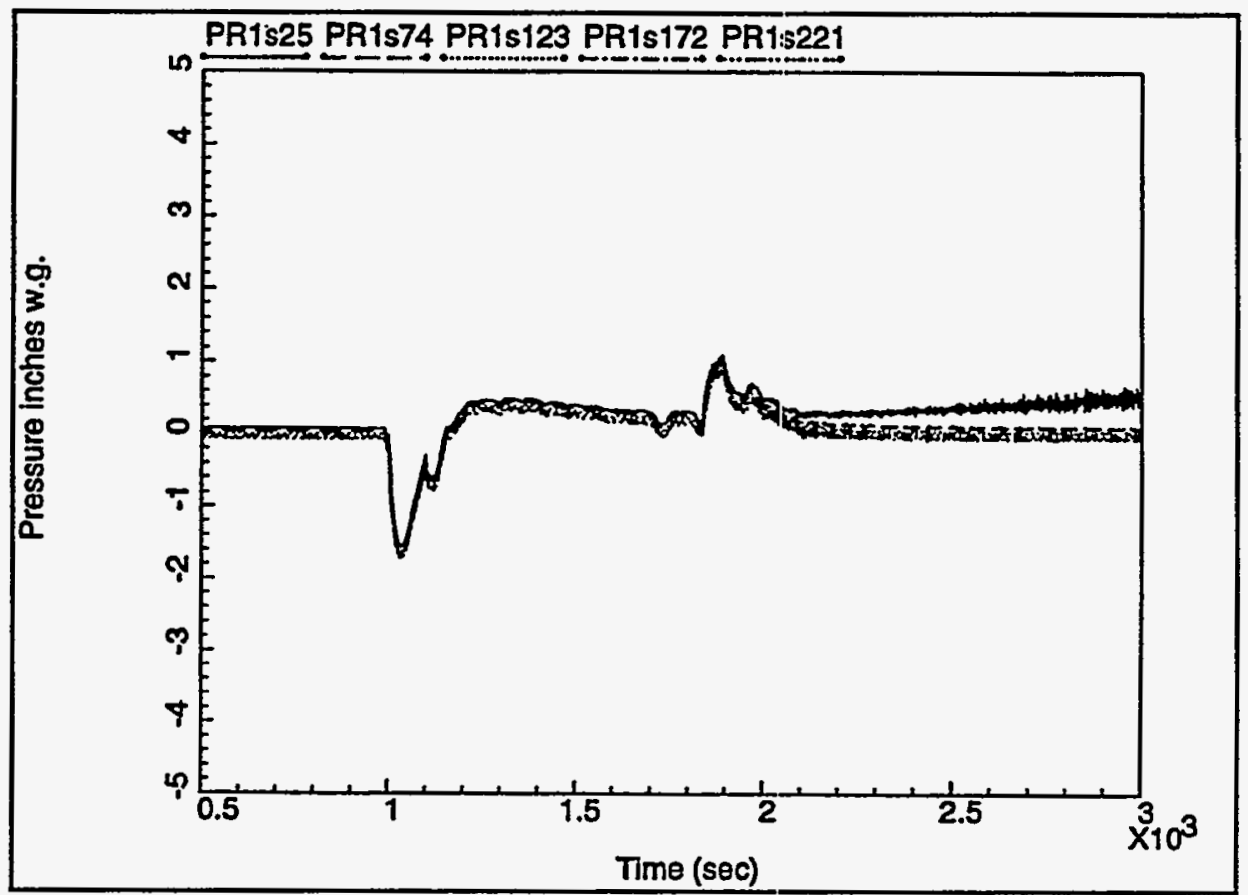

Figure 12 Pressure vs Time Plot for Case 9.

\subsection{COMPARISON OF GOTHIC PREDICTED RESULTS TO HISTORICAL DATA FROM WATER LANCING}

GOTHIC was used to model the water lancing which occurred at 6:48 AM on JuTy 3, 1993 in 101-SY. GOTHIC predicted results for tank dome pressure are shown in Figure 13. The pressure actually measured in the tank dome during lancing, as recorded by the DACs, is shown in Figure 14. What is observed in comparing the two figures is that GOTHIC predicts the shape of the curve (ie. pressure becomes more negative, and then increases above the initial $498.2 \mathrm{~Pa}$ \{2" wg\} vacuum), but is off with respect to the magnitude of the change, erring on the side of conservatism. In fairness to the code however, in the GOTHIC model the sprays were oriented horizontally, as opposed to the $45^{\circ}$ angle down from horizontal as they are on the actual lance. As such, water sprayed from the lance in the model interacts with the air in the dome to a much greater extent then occurred in actual practice.

\subsection{PRESENT CONTROLS FOR WATER WAND OPIERATION}

The present Safety Assessment, LA-UR-92-3196, Rev 12, provides the following controls for use of the spraywands during mitigation pump removal:

- HATER TEMPERATURE: Water temperature must be no less than the dome temperature and no greater than the lesser of $11{ }^{\circ} \mathrm{C}\left(20^{\circ} \mathrm{F}\right)$ higher than the dome temperature or $54.4^{\circ} \mathrm{C}\left(130^{\circ} \mathrm{F}\right)$ unless authorized by the TRG. (Page 6-49) 
WHC-SD-WM-ES-335

Rev. 0

Page 10 of 13

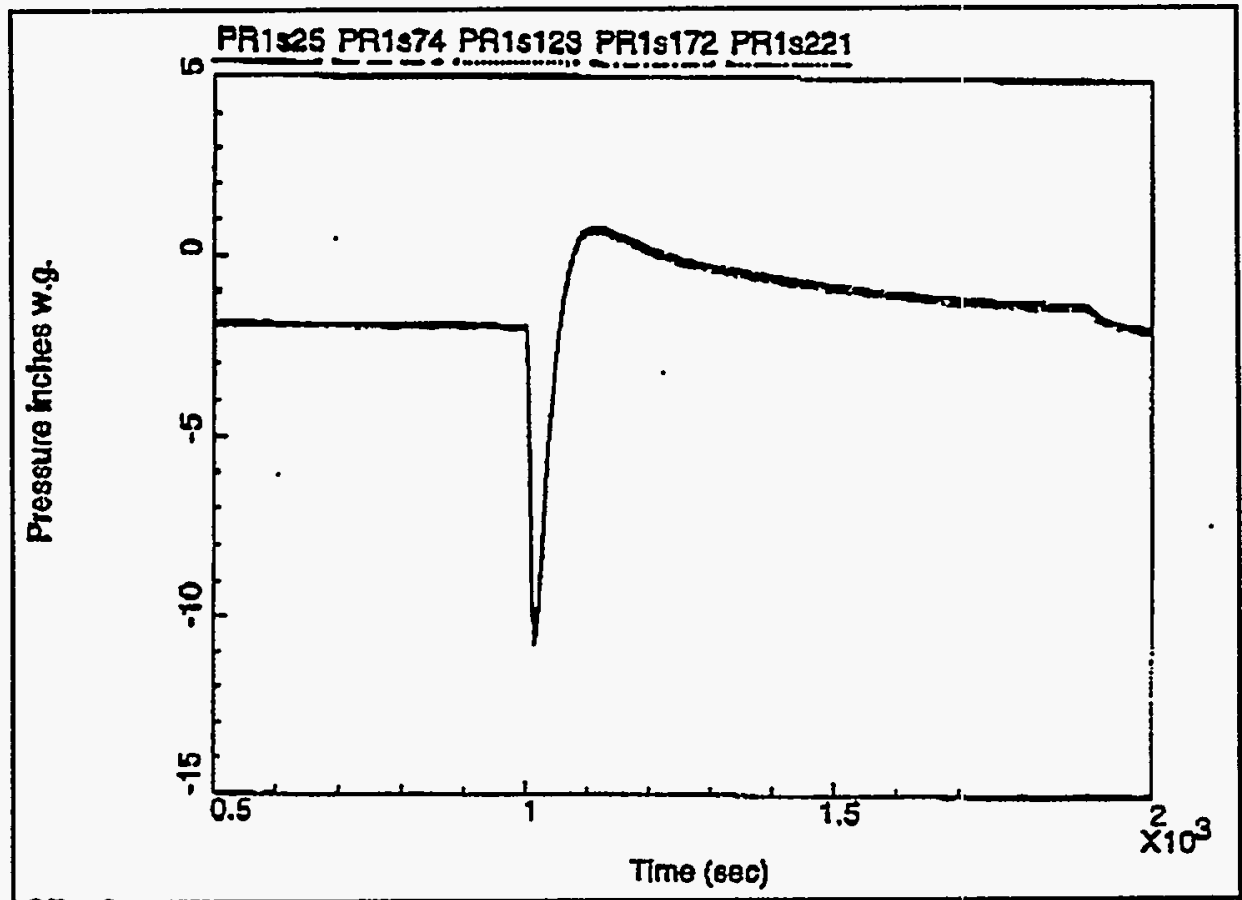

Figure 13 GOTHIC Predicted Pressure vs Time Plot For Hater Lancing.

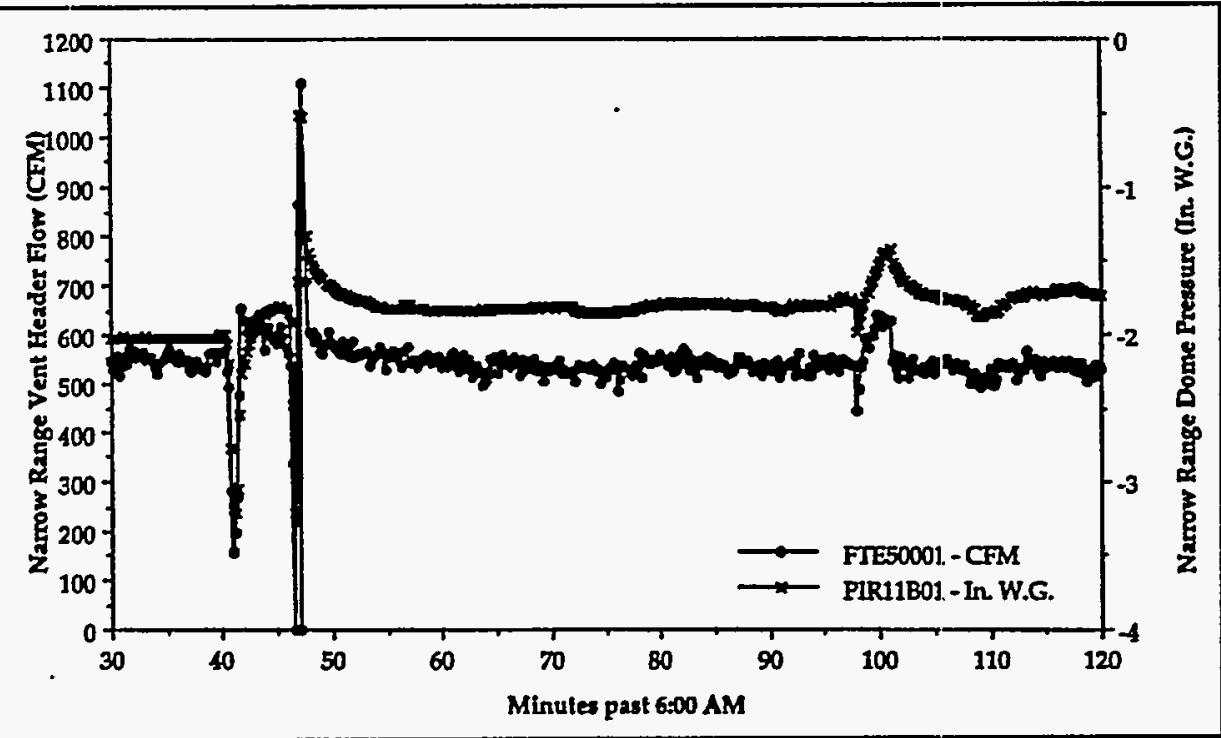

Figure 14 Pressure vs Time PTot Data from DALs for Water Lancing . 
HHC-SD-WM-ES-335

Rev. 0

Page 11 of 13

- MINIMUM DOME PRESSURE: The minimum dome pressure may not be less than $-1494.5 \mathrm{~Pa}\left(-6^{\prime \prime} \mathrm{wg}\right)$. Dome pressure is to be continuously monitored, with an alarm at $-996.3 \mathrm{~Pa}\left(-4^{\prime \prime} \mathrm{wg}\right)$. (Page 6-48)

- MAXIMUM DOME PRESSURE: $+373.62 \mathrm{~Pa}\left(+1.5^{\prime \prime} \mathrm{wg}\right)$. Dome pressure is to be monitored continuously, with an alarm at $+373.62 \mathrm{~Pa}\left(1.5^{\prime \prime} \mathrm{wg}\right.$ ). (Page 648)

- WAND FLOW RATE: The flow rate of the wands must be controlled such that the dome pressure remains within $\pm 249 \mathrm{~Pa}(1 " \mathrm{wg})$. The maximum ramp rate in flow for each wand is 2 minutes, from 0 to full flow. The water wand operator will be in continuous contact with the person monitoring dome pressure. The water lines shall be equipped with two valves in series, one for slowly increasing the flow, another for quickly closing the flow. Water flow is to be immediately terminated if the dome pressure gets outside the $\pm 249 \mathrm{~Pa}\left(1^{11} \mathrm{wg}\right)$ pressure control band. Operations is then to wait for the dome pressure to stabilize before resuming water wand operation.

It should be noted that the controls established for spraywand flow rates tend to make the minimum and maximum dome pressure controls redundant. They are also overly conservative with respect to allowable tank vacuum, and could result in unnecessary exposure to personnel performing the task, and additional expense not technically justified.

Controls identified here are provided for within the work plans for mitigation pump removal, or incorporated into the design of spraywand hardware as appropriate.

\section{. 4.0 PROPOSED CONTROLS FOR WATER WAND OPERATION}

An interest in establishing a procedural control which limits the maximum positive tank dome pressure to $24.91 \mathrm{~Pa}(0.1 " \mathrm{wg})$ has been expressed. There are a number of factors related to the ability to accurately calculate and measure tank dome pressures so close to atmospheric which should be considered prior to insertion of an administrative control so restrictive. What follows is an attempt to identify some of those factors.

\subsection{ISSUES SURROUNDING PRESSURE/FLOH CALCULATIONS}

For a water addition of $681 \mathrm{~L} / \mathrm{min}(180 \mathrm{gpm})$, approximately $681 \mathrm{~L} / \mathrm{min}$ (24 CFM) of air will be displaced. Once a Steady State, Steady Flow (SSSF) condition has been achieved (ie. tank dome pressure has normalized), there are a number of variables which will affect the accuracy of any pressure/flow calculations for the displaced air, and resultant dome pressure. Recalling that flow is a result of a pressure differential, particular emphasis must be placed on those which could impinge flow, with a corresponding increase in dome pressure. Some of these include:

Moisture Content of Air: Saturated air passing through a HEPA filter will tend to load the filter with water. During sub-freezing temperatures, this may translate to an ice build up on the atmospheric side of the filter. Any of these effects would require an increase in dome pressure to induce flow across the filters. 
WHC-SD-WM-ES-335

Rev. 0

Page 12 of 13

HEPA Filter Cleanliness: The cleaner the filter, the lower the pressure drop.

Moisture Separator: Similar to the HEPA filter, some unknown differential pressure drop will be required to move air through the separator.

Leak Paths: To make an accurate calculation of dome pressure, it will be necessary to know the flow rates for all of the leak paths (other than through the inlet and exhaust HEPA filters), as a function of the pressure differential between the tank dome and the atmosphere. If we assume these Teaks to be zero, an increase in dome pressure should be expected, as a pressure differential sufficient to cause flow across the HEPAs would have to be generated.

Pump Removal Rate: Obvious7y, as the pump is removed from the tank, the tank realizes a corresponding increase in volume, reducing the amount of air which must be removed to allow for water addition.

Heat Transfer Effects: Speaks to water vapor, thermal expansion effects at the waste surface/decon water interface. Heating of the air at this interface would result in an increase in the specific volume of the air.

Most of the factors identified above speak to flow restrictions which would effect the ability of the displaced air to flow from the tank, with a resulting increase in dome pressure. In a phone conversation held on November 14 with an engineering representative of $\mathrm{Fl}$ anders (manufacturers of HEPA fi7ters), it was stated that a minimum $24.91 \mathrm{~Pa}\left(0.1^{\mathrm{N}} \mathrm{WG}\right)$ pressure differential would be required to cause flow across the SY HEPA filters. This value was extrapolated from a performance database, which contains data obtained during performance testing of the filters between $20-100 \%$ of rated flow. There is a general measure of skepticism regarding this number however, as $(681 \mathrm{~L} / \mathrm{min}) 24 \mathrm{CFM}$ is approximately an order of magnitude below the lowest bound of filter testing.

To this minimum value of $24.91 \mathrm{~Pa}(0.1 \mathrm{l})$, pressure losses across the demisters and friction losses in the duct must also be accounted for.

Unfortunate7y, pressure drop across the demister is unknown, and I have been unabie to locate anything which would even begin to suggest what the pressure losses would be for a $681 \mathrm{~L} / \mathrm{min}$ (24 CFM) flow rate in a $30.48 \mathrm{~cm}$ (12" duct) would be, al though certainly very small.

\subsection{PRESSURE MEASUREMENT RELATED ISSUES}

Instrumentation used to measure dome pressure in risers $11-B$ and 17-B have a resolution of $2.49 \mathrm{~Pa}\left(0.01^{\prime \prime} \mathrm{wg}\right)$, with an accuracy of $\pm 12.45 \mathrm{~Pa}\left(0.05^{\mathrm{N}}\right.$ $w g)$ at GMS-1. This trans 7 ates to a measurement error of $\pm 50 \%$ with respect to the $24.9 \mathrm{~Pa}(0.0036 \mathrm{psi})$ pressure differential we would hope to measure. The error would increase on the way to the DACs, a result of the analog to digital conversion.

Another factor to be considered would be how to handle the discrepancy between the values reported by the two instruments. Past data indicate pressure readings approximately $49.8 \mathrm{~Pa}\left(0.2^{\prime \prime} \mathrm{wg}\right)$ higher in riser 11-B than those recorded in 17-B, representing a $200 \%$ difference in agreement between the instruments at the proposed delta $\mathrm{P}$. 
Rev. 0

Page 13 of 13

Due to the near zero measurement we would be attenipting to make, additional considerations would include the effect of humidity on instrument accuracy, and where the atmospheric pressure is sensed. The dependence on sensing location can best be demonstrated by example. If atmospheric pressure sensors are located in a "shack," DP measurements could be significantly impacted by the operation of an air conditioner, fans, heater operation, etc..

\subsection{SUMMARY}

Water addition to 101-SY during mitigation pump decon is estimated at $681 \mathrm{~L} / \mathrm{min}$ (180 GPM), and wi7l displace $681 \mathrm{~L} / \mathrm{min}$ (24 CFM). If all the displaced air is assumed to flow through a single $30.4 \mathrm{~cm}$ (12" riser) $\left(A=0.07297 \mathrm{~m}^{2}\left[0.7854 \mathrm{ft}^{2}\right]\right)$, the resultant velocity is $0.1552 \mathrm{~m} / \mathrm{sec}(30.56$ $\mathrm{ft} / \mathrm{min})$, regardless of pressure. If both inlet and outlet HEPA filters are considered, air velocities drop to approximately $.0762 \mathrm{~m} / \mathrm{sec}$ (15 feet/min). Either of these velocities should be considered well below the capture velocity required to remove any particulate from the tank.

Pressure will continue to build in the dome until sufficient to overcome any impediment to flow. The difficulties associated with quantifying those impediments, and developing any meaningful approximation of tank dome pressure without error bars larger than the proposed allowable differential pressure, if not insurmountable, would at least be impractical to solve. It is important to understand that regardless of differential pressure, air flows wi11 not exceed $681 \mathrm{~L} / \mathrm{min}$ (24 CFM).

The difficulties associated with the measurement of near zero differential pressures are difficult to overcome. As the difference approaches zero, the percentage error goes to infinity, and the significance of normally trivial factors become large, regardless of how good your instrument is.

As such, the GOTHIC code which was used to model tank dome behavior indicates a SSSF dome pressure of $124.54 \mathrm{~Pa}\left(0.5^{\prime \prime} \mathrm{wg}\right)$. To set an administrative control less than this value seems excessive. Even at this pressure, instrumentation error would be $10 \%$.

\subsection{CONCLUSIONS AND RECONHENDATIOINS}

Controls for operation of the spraywands during mitigation pump removal are clearly defined by the Safety Assessment. It could be argued that with respect to 1 imiting dome pressure to $\pm 249 \mathrm{~Pa}$ ( $I^{\prime \prime} \mathrm{wg}$ ) is excessive, and will result in unnecessary expense, and exposure to personnel. To further reduce the pressure band allowed for wand operation to $\pm 24.9 \mathrm{~Pa}\left(0.1^{\mathrm{w}} \mathrm{wg}\right)$ could very well prevent the use of the spraywands, and would require an upgrade to the instrumentation used to monitor dome pressures. These upgrades would be expensive, as measuring zero costs money.

Westinghouse must verify that the hardware designed for the spraywands and the work plan which defines their use incorporate the controls identified by the safety' assessment. 